\title{
POSITIVE COEXISTENCE AND BULLYING PREVENTION: THE CONTRIBUTIONS OF THE SUPPORT SYSTEM BETWEEN EQUALS - A STUDY BETWEEN THE SPANISH AND BRAZILIAN EXPERIENCES
}
A CONVIVÊNCIA POSITIVA E A PREVENÇÃO DO BULLYING: AS CONTRIBUIÇÕES DOS SISTEMAS DE APOIO ENTRE IGUAIS - UM ESTUDO ENTRE AS EXPERIÊNCIAS BRASILEIRA E ESPANHOLA

\section{LA CONVIVENCIA Y LA PREVENCIÓN DEL BULLYING: LAS CONTRIBUCIONES DE LOS SISTEMAS DE APOYO ENTRE IGUALES - UN ESTUDIO ENTRE LAS EXPERIENCIAS BRASILEÑA Y ESPAÑOLA}

\author{
Luciene Regina Paulino Tognetta ${ }^{1}$ \\ José Maria AVILÉS Martínez² \\ Darlene Ferraz Knoener ${ }^{3}$ \\ Ana Luiza Aparecida de Matos ${ }^{4}$ \\ Sanderli Aparecida Bicudo Bomfim 5
}

\begin{abstract}
Numerous studies have warned the urgent necessity for educational institutions to organize a systematic, planned and intentional program so that coexistence in school becomes a valuable asset. Furthermore, both studies and legislation on education emphasize the need for schools to carry out specific actions to counter and prevent violence manifestations, including bullying. This paper presents partial data of the establishment of a Support System between Equals model called Help Teams in Brazilian and Spanish schools. The sample consisted of 1,191 students from secondary schools in different cities of São Paulo State and several schools in Spain. The instrument used for data collection was INSEBULL, a specific questionnaire for the diagnosis of typical bullying situations. The results show that youth protagonist is one of the possible solutions to overcome bullying in the school environment.
\end{abstract}

Keywords: School coexistence. SAI (Support Systems Between Equals). Bullying. protagonist.

Resumo: Inúmeras investigações alertam para a necessidade urgente de que as instituições de educação organizem programas sistemáticos, planejados e intencionais para que a convivência na escola seja um valor. Ademais, tanto pesquisas como as legislações sobre educação ressaltam a necessidade de que as escolas tenham ações específicas de combate e prevenção às manifestações

\footnotetext{
${ }^{1}$ São Paulo State University (UNESP). Araraquara, São Paulo, Brazil.

${ }^{2}$ University of Valladolid (Uva). Valhadolide, Spain.

${ }^{3}$ São Paulo State University (UNESP). Araraquara, São Paulo, Brazil.

${ }^{4}$ São Paulo State University (UNESP). Araraquara, São Paulo, Brazil.

${ }^{5}$ São Paulo State University (UNESP). Araraquara, São Paulo, Brazil.
} 
de violência, dentre elas o bullying. A presente investigação apresenta dados parciais da implantação de um modelo de Sistema de Apoio entre Iguais denominado Equipes de Ajuda em escolas brasileiras e espanholas. A amostra foi composta por 1.191 estudantes de escolas secundárias de diferentes cidades do Estado de São Paulo e diversas escolas da Espanha. O instrumento utilizado para a coleta de dados foi o INSEBULL, um questionário específico para o diagnóstico de situações de típicas de bullying. Os resultados demonstram que o protagonismo juvenil é uma das soluções possíveis para a superação bullying no contexto da escolar.

Palavras-chave: Convivência escolar. SAI (Sistemas de Apoio entre Iguais). Bullying. Protagonismo.

Resumen: Numerosas investigaciones advierten de la urgente necesidad de que las instituciones educativas organicen programas sistemáticos, planificados e intencionales para que la convivencia en la escuela sea un valor. Además de eso, tanto investigaciones como las legislaciones sobre educación señalan la necesidad de que las escuelas tengan acciones específicas de combate y prevención a las manifestaciones de violencia, entre ellas el bullying. Esta investigación presenta datos parciales de la implantación de um modelo de Sistema de Apoyo entre Iguales denominado Equipos de Ayuda en escuelas brasileñas y españolas. La amuestra se compuso por 1.191 estudiantes de escuelas secundarias de diferentes ciudades del Estado de São Paulo y diversas escuelas de España. El instrumento utilizado para la recolecta de datos fue el INSEBULL, uma encuesta específica para el diagnóstico de situaciones típicas de bullying. Los resultados demuestran que el protagonismo juvenil es una de las soluciones posibles para la superación bullying en el contexto escolar.

Palabras clave: Convivencia escolar. SAI (Sistemas de Apoyo entre Iguales). Bullying. Protagonismo.

\section{INTRODUCTION}

The scenes of manifestations of indiscipline and violence are common in Brazilian educational institutions. Although schools establish as a goal the search for the formation of fairer, more respectful, supportive and autonomous people, problems such as aggression, bullying, among others, compromise the construction of a respectful and more cooperative coexistence in the school environment (TOGNETTA et al., 2017). In this context, it is possible to accompany experiences and attempts of an intentional work with social-emotional and moral values, however, they are usually punctual and short-term actions (MENIN; BATAGLIA; ZECHI, 2013; FRICK et al., 2019).

Data from different national and international investigations indicate the urgent need for planned, systematic and intentional actions to prevent and combat violence at the school environment, especially bullying, to be organized by all schools. An example of this urgency are the results from the Programme for International Student Assessment (PISA) (INEP, 2019a) indicating that coexistence in Brazilian schools tends to be competitive, therefore, opposed to an atmosphere of cooperation, reciprocity and democracy that enables a positive coexistence and contributes to the ethical development and citizenship of each student. 
Within this context, one of the problems of coexistence that is quite evident is bullying, which is characterized as a form of physical and/or psychological violence that occurs between peers and in front of spectators, but far from the eyes of authority, in which a person (or a group of people) repeatedly and intentionally acts against others with the intention of hurting or intimidating them, since there is an imbalance of power between the author and the target (OLWEUS, 1993; 1997; AVILÉS MARTÍNEZ, 2009; DEL BARRIO et al., 2003; TOGNETTA et al., 2010; SILVA; CAMINHA, 2014; LEOPOLDINO; SANTOS; CAMINHA, 2020). This is not a normal conflict in everyday relationships, but rather a form of cruel violence, precisely because it affects the representations that the subjects have of themselves ${ }^{6}$ (TOGNETTA, 2005).

Data from the Programme for International Student Assessment (PISA) 2015 (MEC, 2017) indicated that one in ten Brazilian students suffered from bullying at school. However, in the 2018 evaluation, about three out of ten said that they experienced bullying "a few times a month" and many reported that they felt solitary at school. In addition, in the two weeks prior to the data collection, $50 \%$ of students missed a day or arrived at school later (IDOETA, 2019; INEP, 2019a; INEP 2019b), as it may have a correlation with systematic bullying practices, since previous research has concluded that students who are frequent targets of bullying are more likely to miss classes (JANOSZ et al., 2018).

It is not by coincidence that in 2015 the Brazilian National Congress approved Law 13.815/15, known as the Anti-Bullying Law, affirming the importance of society and the school being concerned about the occurrence of this phenomenon of violence. Article 5 establishes that: "It is the duty of the educational establishment, clubs and recreational associations to ensure measures of awareness, prevention, diagnosis and combating violence and systematic intimidation (bullying)" (BRAZIL, 2015, our translation).

Article 6 of the law also states that actions must include a systematic diagnosis indicating the need to "produce and publish bimonthly reports of occurrences of systematic intimidation (bullying) in states and municipalities in order to plan actions" clarifying in article 7 that the work can be enhanced through joint actions between the State and agencies responsible for research on the subject, indicating that "the federated entities may sign agreements and establish partnerships for the implementation and correct execution of the objectives and guidelines of the Program" (BRAZIL,

\footnotetext{
${ }^{6}$ Representations regarding the ideal images and the real images that each person projects onto themselves, also considering what others think about them. It is a "self-awareness" that is not innate, because at approximately 18 months of life "the child finds him/herself as an object among other objects" (LA TAILLE, 2002, p. 53) and it's in this process of decentralization that, with time, the subject becomes aware that he/she sees him/herself and that he/she is seen by others, therefore, it is impossible that he/she despises "judgments of others" (LA TAILLE, 2002, p. 68).
} 
2015, our translation). More recently, this law was integrated into the LDB (Law of Guidelines and Bases of National Education) with the amendment of article 12 (Law 13.663) determining that it is the obligation of educational establishments: "IX - to promote measures to raise awareness, prevent and combat all types of violence, especially systematic intimidation (bullying), within schools; $\mathrm{X}$ - to establish actions aimed at promoting the culture of peace in schools" (BRAZIL, 2018, our translation). Although these are extremely important legislative milestones as incentives for the organization of better coexistence in Brazilian schools, there is a long way to go, also because it is such a recent discussion from a legal point of view, since this need was already pointed out by international studies since the first investigations on bullying from the 1970s (OLWEUS, 1993; 1997). A decade earlier, law 27/2005 had already been sanctioned in Spain as a law to "promote education and the culture of peace" and complements law 21/2003 which also dealt with "teaching and education for peace" (JARES, 2008, p. 114-116). Similarly, the Spanish law also recognizes the importance and that the actions implemented by the schools be guided with the support of "researchers and experts from the world to work on the structure and lines of action for the promotion of peace" (JARES, p. 116, our translation).

In agreement with the needs pointed out by the research that has been recently ratified by the laws, the Moral Education Study and Research Group (GEPEM) by Unesp/Unicamp, elaborated the program "Ethical coexistence in school" developed in different public and private institutions of Elementary and Secondary Education of the State of São Paulo since 2015. It is a management and teacher formation program, with an average duration of 24 months, with the purpose of generating transformations in the school from proposals of differentiated actions inserted in the curriculum aiming at mediating conflicts, improving the quality of coexistence and the consequent reduction of violence, enabling the construction of a positive and beneficial school climate ${ }^{7}$ for development and adherence to moral values (VIVALDI, 2020).

The program was conceived considering three interrelated tracks: personal, curricular and institutional (VINHA et al., 2017). The actions involve the preventive, curative and fostering dimensions and, in summary, consist of: the insertion of a 90-minute weekly subject in the curriculum of students in the final grades of elementary school (and also a weekly space in the initial grades of elementary school), so that coexistence and morals are systematically discussed; in the weekly/fortnightly formation for the professionals of these schools, with the introduction of

\footnotetext{
${ }^{7}$ By school climate, it is understood here the perception of the quality of experiences at school that is based on patterns of experiences of the people who coexist there and reflects norms and objectives, values, interpersonal relationships, teaching and learning practices and organizational structures (COHEN et al., 2009).
} 
collective construction cycles; in the fortnightly formation directed only to managers and reference teachers (who are responsible for the new discipline and the tutoring of the students of the Help Teams); in the implementation of spaces for participation, resolution and mediation of conflicts; in the construction of a Coexistence Plan in the educational institutions and in the monitoring by sampling of the main procedures implemented; and the participation of school professionals in an online collaborative environment through responsive assessments ${ }^{8}$ and school climate.

In this same program, there is an important proposal of youth protagonist, highlighted in this research: the implementation of a model of Support Systems Between Equals, SAls (AVILÉS MARTÍNEZ, 2017; 2018). This work seeks to promote youth empowerment by allowing students to organize themselves to provide support services to their peers, from the company to help or mediation (GARTNER; KOHLER; RIESSMAN, 1971; SLAVIN, 1995). This type of action is consistent with theoretical assumptions underscored by research on value education, which states that the subject builds his values in processes of interaction with objects, people and oneself (PEREIRA et al., 2017, 27).

The first practices of support between equals were established as a tool for solving problems of coexistence since the seventies in the Canadian and American educational tradition (NAYLOR, 2010). Later, they appeared in British Isles and from there all over Europe. In Spain, the SAls were only incorporated in the 1990s and were related to conflict resolution and mediation initiatives. Subsequently, they were also developed and presented as support to situations of prevention of maltreatment among peers, and today they have a very wide extension in Spanish schools, although not widespread.

In Brazil, the work with SAls that started in 2015 (AVILÉS MARTíNEZ, 2013b) already shows very encouraging results (LAPA, 2019; BOMFIM, 2019). The model adopted within the "Ethical coexistence at school" program is called "Help Teams" because it stands out as a support whose support is cooperation among peers (AVILÉS MARTíNEZ, 2012; 2013a; 2017; 2018; AVILÉS MARTÍNEZ; TORRES; VIÁN, 2008). Originally developed by Avilés in Spain, the program was adapted and reconstructed according to the Brazilian reality (TOGNETTA et al., 2017).

Among the many actions aimed at the members of the Help Teams, we can highlight actions in individual and collective spheres. Regarding individual issues, we highlight the following: 1)

\footnotetext{
${ }^{8}$ Model of democratic evaluation that takes into account the knowledge of the school itself and of the teaching staff to promote constant reflections, improvements and necessary communications. It also aims to evaluate the program by responding to beneficiaries about what is happening, in addition to welcoming questions, ideas and suggestions about what can be improved.
} 
Welcoming newcomers and facilitating their integration into the group; 2) Helping those students who feel excluded, have personal difficulties, need to be listened to or need company; 3 ) Helping their companions when someone messes with them; 4) To detect conflicts, analyze them, and seek possible solutions interventions or referrals; 5 ) To help students who seek self-isolation as a way of resolving conflicts; 6) To integrate those who have no acquaintances or friends into the group; 7) To listen to those who are experiencing emotional problems, sad situations, or bad personal moments; 8) To have empathetic listening for those who present fear or irrational ideas; 9) To help those who present great timidity in interpersonal relationships; 10) To help those who suffer situations of abuse between equals, such as bullying and cyber aggressions (AVILÉS MARTíNEZ, 2018).

The participants of the Help Teams are chosen by their colleagues based on reliability criteria. They are, in the view of their peers, the ones who have the best conditions to help anyone, beyond the friendly relations. It is well known that from a psychological point of view, as Piagetian theory has pointed out to us since 1932, peers are indispensable in the formation of the ethical personality of those with whom they relate. Adolescents, for example, think that it is always worse to lie to a colleague than to an authority. By lying to an authority, one breaks obedience, but by lying to a peer, one breaks trust - something much more valuable: a parent doesn't stop being a parent for having received a lie. But a friend, in breaking the trust, can stop being one (PIAGET, 1994).

We also emphasize that the idea of working only with elementary school students is not random. It is a fact that one of the child's first interpersonal feelings is sympathy, and this makes the child more generous than fair. To help the other child is necessary, but not enough. This is because, moved by sympathy, the child will help, but may take the problem for oneself, because he/she still can't separate what is his/her from what is the other and may suffer from it. In adolescence, with the most evolved thought - hypothetical-deductive - the individual is able to see the other as a universal being and because they have already expanded their list of relationships beyond family and friends, they are already able to think about the values of the group (PIAGET, 1994).

In brief, the different proposals of the program presuppose the establishment of an environment in which decisions are generally taken seeking consensus through dialogue and collective responsibility for compliance with agreements. Relationships are continuously sought based on respect in which the rules are clear and linked to basic rights. Sanctions are fair based on principles of equity and reciprocity. It is also necessary to offer a set of educational strategies in the formation of students who are protagonists in the prevention of problems of coexistence. The 
interventions in conflicts, considered natural in interpersonal relations, must opportunize the learning of dialogical and cooperative processes in their resolution. Furthermore, it is important to have an institutional process of mediation of collective and particular conflicts, as well as assertive strategies to face school violence.

In this paper, our research problem is to find out if a support system like the Help Teams positions students differently regarding bullying situations in groups, times, and schools where this model of SAI is not present.

\section{METHOD}

This study aims to present some results on how the implementation of these support systems has worked for the improvement of relations between students in educational centers in Brazil and Spain.

Evidence of the influence of Help Teams in Spain and Brazil is measured in two situations: from the percentages of incidents of bullying in the coexistence of groups; and the positioning of subjects in these scenarios (whether as authors, targets, or spectators).

The data obtained were also compared with schools that have Help Teams and others that do not have the system in place. This research is a cut of a larger investigation that aims to compare results between teachers and students of these schools (where there is the implementation of Support Systems and where there is not) in Brazil and Spain.

\subsection{SAMPLE}

In Brazil, the total sample included students from public and private schools in the metropolitan regions of Campinas, São Paulo, Araraquara, all cities in the State of São Paulo. Of a total of 756 students from 11 to 14 years old in Elementary School II (which corresponds to Secondary Education in Spain), 39.5\% (302 students) were students from schools where the work with the Help Teams was not implemented and 60.05\% (454 students) made up the sample of students where such system was implemented.

In Spain, as shown in Table 1, two samples are compared, one of 241 boys and girls who participate in Help Teams program and the other of 197 boys and girls who do not participate, between the ages of 11 and 14, from different schools in Valladolid, Madrid, Guadalajara, A Coruña and Barcelona. The equality of the groups was verified by comparing their variances, contrasting their means and through the Levene test. 
Table 1 - Distribution by treatment and sex of the Spanish sample

\begin{tabular}{|c|c|c|c|}
\hline Sample & Boys & Girls & Total \\
\hline With Help Teams & $\mathbf{1 2 2}(51,4 \%)$ & $\mathbf{1 1 9}(48,6 \%)$ & $\mathbf{2 4 1}(55,02 \%)$ \\
\hline Without Help Teams & $\mathbf{1 0 8}(54,9 \%)$ & $\mathbf{8 9}(45,1 \%)$ & $\mathbf{1 9 7}(44,98 \%)$ \\
\hline Total & $\mathbf{2 3 0}(52,52 \%)$ & $\mathbf{2 0 8}(47,48 \%)$ & $\mathbf{4 3 8}(100 \%)$ \\
\hline
\end{tabular}

\subsection{INSTRUMENTS}

The measurement of the prevalence of bullying in the groups of both countries was performed through data collection using INSEBULL ${ }^{9}$, through its self-report (AVILÉS MARTíNEZ; ELICES SIMÓN, 2007), which was validated by the main nonlinear component method (princals) and expert judgment (Alpha $=$, 9634). Its reliability obtained a Cronbach's alpha of 0.8878 of internal consistency.

In Brazil, in public schools, data were collected in the printed version and through Google Forms in private schools. In Spain, only using Google Forms in the computers of the centers. In both countries, the ethical procedures required for this type of research were maintained and are described in the surveys that make up the first phase of the evaluation of the implementation of the model.

\section{PROCEDURE}

In Spain and Brazil, the participants in the research were the students of the Help Teams and the recipients of the service; teachers involved in the development of the program "The Ethical Coexistence in School" and other teachers of the schools. The Help Teams and the teachers in charge received the necessary training to develop the work, and the students participated in a two-day training course in which contents about coexistence, conflict resolution, communication, empathy, assertiveness and teamwork were developed. The faculty prepared in advance for this training and specific materials were developed to carry out the course (AVILÉS MARTÍNEZ; ALONSO, 2017a; 2017b).

\section{RESULTS}

However, there is a significant difference when evaluated as bystanders, as shown in table 2 where we present the answers given to item 26 of the questionnaire How often have there been

\footnotetext{
${ }^{9}$ INSEBULL (AVILÉS MARTÍNEZ; ELICES SIMÓN, 2007) is a software application that integrates a self-informative 36 items and an abuse sociogram.
} 
intimidation (putting nicknames, humiliating classmates, grabbing, punching, pushing, threatening, isolating, etc.) in your school during the past three months?. In schools without a Help Team (No) $10.3 \%$ stated that intimidation occurs every day and in schools with a Help Team (Yes) the percentage is $6 \%$.

Table 2 - Responses to item 26 of the INSEBULL-Spain questionnaire - Perception of participants classified as spectators

\begin{tabular}{lcccc}
\hline \multirow{2}{*}{$\begin{array}{l}\text { How often have there been intimidation in } \\
\text { your school? }\end{array}$} & No & Yes & Total & p- value \\
\cline { 2 - 3 } & $32(17,3 \%)$ & $89(37,9 \%)$ & 121 \\
Never & $75(40,5 \%)$ & $89(37,9 \%)$ & 164 \\
Less than five times & $46(24,9 \%)$ & $23(9,8 \%)$ & 69 & $<0,01$ \\
Between five and ten times & $7(3,8 \%)$ & $8(3,4 \%)$ & 15 & 18 \\
Between ten and twenty times & $6(3,2 \%)$ & $12(5,1 \%)$ & 33 \\
More than twenty times & $19(10,3 \%)$ & $14(6 \%)$ & 320 \\
Every day & 185 & 235 & 42 \\
\hline Total & Source: elaborated by the authors. &
\end{tabular}

In Brazil, for this same item of the questionnaire a significant difference ( $p$-value $<0.01)$ was also obtained between schools with Help Teams and without Help Teams, drawing our attention to the fact that $24.5 \%$ of students in schools where there are no Help Teams suffer intimidation every day, as can be seen in table 3 .

Table 3 - Responses to item 26 of the questionnaire INSEBULL - Brazil - Perception of participants classified as spectators

\begin{tabular}{|c|c|c|c|c|}
\hline \multirow{2}{*}{$\begin{array}{l}\text { How often have there been } \\
\text { intimidation in your school? }\end{array}$} & \multicolumn{2}{|c|}{ Help Teams } & \multirow{2}{*}{ Total } & \multirow{2}{*}{ p-value } \\
\hline & No & Yes & & \\
\hline Never & $130(43,05 \%)$ & $156(34,44 \%)$ & 286 & \\
\hline Less than five times & $52(17,22 \%)$ & $121(26,71 \%)$ & 173 & \\
\hline Between five and ten times & $28(9,27 \%)$ & $88(19,43 \%)$ & 116 & \\
\hline Between ten and twenty times & $6(1,99 \%)$ & $25(5,52 \%)$ & 31 & $<0,01$ \\
\hline More than twenty times & $12(3,97 \%)$ & $16(3,53 \%)$ & 28 & \\
\hline Every day & $74(24,5 \%)$ & $47(10,38 \%)$ & 121 & \\
\hline Total & 302 & 453 & 755 & \\
\hline
\end{tabular}

When we compare the results of this same item on the frequency of intimidation according to those who are spectators of violence in Brazil and Spain, the results show that the differences are 
significant ( $p$-value $<0.01$ ) between Spanish and Brazilian schools that do not implement these systems, as we can see in table 4. In Brazilian schools, almost double the frequency of intimidation happens daily (24.5\% for the Brazilian sample and $10.27 \%$ for the Spanish sample).

Table 4 - Spain and Brazil comparison of responses to item 26 of the INSEBULL questionnaire in schools WITHOUT the Help Teams - Perception of participants classified as spectators

\begin{tabular}{lcccc}
\hline \multirow{2}{*}{$\begin{array}{l}\text { How often have there been intimidation } \\
\text { in your school? }\end{array}$} & \multicolumn{2}{c}{ Country } & Total & p-value \\
\cline { 2 - 3 } Never & $130(43,05 \%)$ & $32(17,3 \%)$ & 162 \\
Less than five times & $52(17,22 \%)$ & $75(40,54 \%)$ & 127 \\
Between five and ten times & $28(9,27 \%)$ & $46(24,86 \%)$ & 74 \\
Between ten and twenty times & $6(1,99 \%)$ & $7(3,78 \%)$ & 13 & $<0,01$ \\
More than twenty times & $12(3,97 \%)$ & $6(3,24 \%)$ & 18 & 93 \\
Every day & $74(24,5 \%)$ & $19(10,27 \%)$ & 93 \\
\hline Total & 302 & 185 & 487 \\
\hline
\end{tabular}

Source: elaborated by the authors.

What about the schools where the Help Teams operate? It can be seen from table 5 that between Brazilian and Spanish schools where Help Teams operate, there are significant differences ( $p$-value $>0.01$ ) pointing out that the frequency of intimidation (never $-34.44 \%$ in Brazil and $37.89 \%$ in Spain) seems to happen more in Brazil (every day $10.38 \%$ in Brazil and only $5.96 \%$ in Spain) as we can see in table 5 .

Table 5 - Spain and Brazil comparison of responses to item 26 of the INSEBULL questionnaire in schools WITH the Help Teams

\begin{tabular}{llcc}
\hline \multicolumn{1}{c}{$\begin{array}{c}\text { How often have there been } \\
\text { intimidation in your school? }\end{array}$} & \multicolumn{1}{c}{ Country } & Total & p-value \\
\cline { 2 - 3 } & $156(34,44 \%)$ & $89(37,87 \%)$ & 245 \\
\hline Never & $121(26,71 \%)$ & $89(37,87 \%)$ & 210 \\
Less than five times & $88(19,43 \%)$ & $23(9,79 \%)$ & 111 \\
Between five and ten times & $25(5,52 \%)$ & $8(3,4 \%)$ & 33 \\
Between ten and twenty times & $16(3,53 \%)$ & $12(5,11 \%)$ & 28 \\
More than twenty times & $47(10,38 \%)$ & $14(5,96 \%)$ & 61 \\
Every day & 453 & 688 \\
\hline Total & Source: elaborated by the authors.
\end{tabular}


In relation to participant profiles and the management of bullying, in general, students who have Help Teams around are more sensitive to bullying situations and demonstrate a greater degree of awareness of effective responses to resolve it. They turn to faculty to communicate it or ask adults for help in resolving cases. In addition, they are more aware of their emotions when situations occur and recognize their provocations, as demonstrated in table 6 where we present data from responses to item $13 \mathrm{c}$ of the questionnaire: If your companions intimidated you on any occasion, why do you think they did it? c. Because I teased them.

Table 6 - Answers to item 13 of the INSEBULL questionnaire - Spain

\begin{tabular}{|c|c|c|c|c|}
\hline \multirow{2}{*}{$\begin{array}{l}\text { If your companions intimidated you on any } \\
\text { occasion, why do you think they did it? } \\
\text { c. Because I teased them? }\end{array}$} & \multicolumn{2}{|c|}{ Help Teams } & \multirow[b]{2}{*}{ Total } & \multirow[b]{2}{*}{ p-value } \\
\hline & No & Yes & & \\
\hline No & $189(99 \%)$ & $83(34,3 \%)$ & 272 & \\
\hline Yes & $2(1,1 \%)$ & $159(65,7 \%)$ & 161 & $<0,01$ \\
\hline Total & 191 & 242 & 433 & \\
\hline
\end{tabular}

Source. elaborated by the authors.

Taking this same alternative, among Brazilian students there are no significant differences, if we compare the responses of students from schools with and without Help Teams. Likewise, when we compare the Brazilian and Spanish responses, we find that there are no significant differences if we isolate this alternative thus demonstrating that such awareness of this specificity of action is common among both samples as shown in table 7.

Table 7 - Comparison of responses to item 13 of Brazil and Spain questionnaire

\begin{tabular}{lcccc}
\hline \multirow{2}{*}{ Item 13C } & \multicolumn{2}{c}{ Country } & Total & p-value \\
\cline { 2 - 3 } & Brazil & Spain & & \\
\hline No & $288(95,36 \%)$ & $189(98,95 \%)$ & 477 & \multirow{2}{*}{0,03} \\
Yes & $14(4,64 \%)$ & $2(1,05 \%)$ & 16 & 493 \\
\hline Total & 302 & 191 &
\end{tabular}

\section{DISCUSSION}

The percentages on bullying frequency presented in this research reinforce the need for schools to organize themselves into programs to overcome violence in their settings. Especially the responses from participants in the Brazilian sample point to the great challenge still facing educational institutions. 
At the same time, the results found also reinforce others previously presented by Avilés Martínez, Torres and Vián (2008), Cowie and Wallace (2000); Cowie and Smith (2002); Menesini et al. (2003) and Naylor and Cowie (2000) suggesting that, in situations of intimidation, where violence occurs between equals in the school environment, the Support Systems Between Equals, called here as Help Teams, become a valuable tool for the prevention of such situations. In addition, the Peer Support System, based on the Spanish model (AVILÉS MARTíNEZ, 2013b) of the Help Teams, currently adopted in some Brazilian schools, allows to channel some concern of the school community when addressing bullying. The implementation of this program has certainly helped raise awareness and awareness among teachers and families about this type of violence.

Again, we emphasize that the option for teamwork was not random, since it brings the idea of a group that operates collectively, in pursuit of the same goal, with a common feeling of support, thus avoiding the overload of responsibility to the individual (AVILÉS MARTÍNEZ, 2018). Furthermore, team members feel more supported in their decisions, increasing the respect and trust of the group of equals with the members of the Helping Team, a factor that enables them to cooperate with others.

According to the results obtained in this sample, both in Spain and Brazil, it was found that the implementation of the Helping Teams Program had no specific impact on the prevalence of bullying among groups. However, other related achievements are observed as the significant difference in aggressors' perceptions of their actions between those who participate in the program and those who do notThe program contributes to make aggressors aware of their actions (MENESINI et al., 2003). The data give evidence of the importance that within the program there is: the decision of new disciplinary and normative models within the educational community; the articulation of possible actions that may compromise students in the resolution of bullying (AVILÉS MARTÍNEZ, 2006; PIKAS, 1989; RIGBY, 1996); and evaluate the effectiveness of other specific actions aimed at combating bullying, taking advantage of the climate of awareness generated by the program.

Among the spectators the program highlights their needs for communication and management of emotions to be better channeled, leading them to reflect on all forms of intimidation that occur, including those that may be more hidden or go unnoticed, and that are no less serious or harmful. This is the case of social abuse, exclusion or isolation due to inaction (AVILÉS MARTÍNEZ; TORRES; VIÁN, 2008).

Among those who suffer the intimidation, it has been found that in schools where there is a 
coexistence program, they are more willing to communicate what happens to them. In this way, their needs for communication and emotional management are better channeled. This happens because they are the same people prepared to support those who are in the best position to help when necessary. SAls allow students, under the leadership of the school's adults, to organize themselves to solve problems that arise in groups, such as conflicts, misunderstandings, isolation, lack of social interaction skills, bullying, or other problems that any student may suffer throughout their schooling. Therefore, they are preventive resources that contribute to the prevention of difficulties that tend to be greater over time, providing students with conditions to develop moral autonomy to take charge of their own problems, managing them and seeking assertive solutions.

These quantitative data are congruent with the qualitative data found by Lapa (2019) in her research. In addition to the quantitative data, the author used the content analysis when categorizing students' answers by asking them what had changed in them after they joined the Help Teams, whether they believed it was necessary for other schools to have Help Teams, what changes in a school the setting up of the Help Teams, how other students see them and whether they liked to participate in the Teams and why. The possibility of open answers brought the verification of seven categories in the students' answers. The first category was called "self-perception gains" and related to aspects that the students did not know about themselves and that were evident in their work on the Help Teams; the second category "the importance of peers" brought elucidation about the positive aspects of conflict and coexistence; the third category "the effects of helping" brought out the positive aspects of the helping process; the fourth category "the perception of those who are not members of the Help Teams" that, according to them, see them in a positive way when working to improve coexistence; the fifth "characteristics of those who help" that opened the search for living the necessary characteristics for the members of the Help Teams; the sixth "the value of those who help" points out how much the students feel value for being able to help those in need and, finally, the last category "the functions of the Help Teams" when the students perceive the function of the team in the environment where they are inserted. Quantitative or qualitative, are data that point out how much this type of SAI is fundamental in the care with relationships and in the construction of a truly ethical coexistence.

\section{CONCLUSIONS}

As Piaget (1994) said, cooperation is the way of balance in which coative relationships tend to go when age differences disappear, or rather, when they become irrelevant. The author would 
also say that the possibility of cooperating - which in purely piagetian terms means operating together - only occurs when there is reciprocity, that is, the common obligation of the partners to put themselves in the other's point of view. In his own words, cooperation "is limited to obliging individuals to 'situate themselves' in relation to each other, without the laws of perspective that result from this reciprocity suppressing particular points of view" (PIAGET, 1994, p. 295, our translation).

Beyond the issue of cooperation, there are many reasons why the work of the Help Teams is done as a group and not individually: Students feel more supported and accompanied by their Teammates; students get used to making decisions in groups and to sharing them; there is the possibility of avoiding inappropriate actions on the part of some of the members; there is the development of the habit of coordinating the different perspectives and reaching an agreement with the rest of the group than is more favorable to do in the most important situations and cases; the individual responsibility will be diminished in the interventions made; unnecessary protagonist will be avoided in the group actions; there is an increase in respect and trust among the peers in general; and finally, the work in Team facilitates the substitution of members during the course or in each new school period.

We can say that the implementation of the Help Systems has contributed to create a very significant climate of awareness against intimidation. This is because in the educational community, problems of coexistence and bullying are discussed, which allows an institutional message to be presented against abuse, and the structures (Help Teams) that enable the intervention are officially supported and make the intervention possible.

In brief, the research data for Spain and Brazil also seem to indicate that Support System Between Equals are a good tool for improving school coexistence and preventing bullying, but other specific measures need to be taken to reduce the prevalence of bullying in schools. These measures need to be organized around what we call the Anti-Bullying Project (AVILÉS MARTíNEZ, 2015), where all members of the educational community participate.

The experience of Brazilian boys and girls shows us that the possibility of giving them a voice and time as protagonists of their own actions, helps them to experience autonomy in schools that helps them to be free in the future. It is worth remembering that the role of protagonist of the students in the Brazilian educational system lacks history, having been relegated to a function that receives orders and fulfills the decisions of authority. This model is a very relevant change. 
In the current investigation, if when confronting students with twenty situations of possible violence, they emit a different evaluation (decrease in violent reactions) after the Help Teams' formation, we can consider a close relationship between this decrease and the direct actions of the Help Teams with them.

It is possible to recognize that the implementation of Help Teams offers a change in the school environment of trust and the presence of moral values, defined daily by violence (AVILÉS MARTÍNEZ; TORRES; VIÁN, 2008).

It will not be possible to overcome problems of coexistence in which bullying is the main issue while we continue, as is the case in Brazil, restricted to public policies that, demonstrating clear theoretical limits in their elaboration, forward primers and awareness campaigns and other strategies for outsourcing school problems (such as the indication of the police at school or even the validation of poorly judged referrals to the guardianship councils). The Anti-Bullying Law, cited above, is quite clear in pointing out the need for more consistent actions aimed not only at containing the problem, but mainly at implementing actions aimed at its prevention, markedly considered in the light of the possibilities of forming the subjects involved in the problem directly or indirectly. It is in consonance not only with the law, but also with the strategies that, for years, national and international researches have shown to be effective in facing the problem, and that our investigations point out gaps in Brazilian education when it comes to the desire for citizen education. Therefore, the challenge is on.

\section{REFERENCES}

AVILÉS MARTÍNEZ, José Maria. Análisis psicosocial del cyberbullying. Claves para una educación moral. Papeles del psicólogo, v. 34, n. 1, p. 65-73, 2013a.

AVILÉS MARTÍNEZ, José Maria. Bullying: el maltrato entre iguales. Agresores, víctimas y testigos en la escuela. Salamanca: Amarú, 2006.

AVILÉS MARTÍNEZ, José Maria. Bullying: Guia para educadores. Campinas, SP: Mercado das Letras, 2013b.

AVILÉS MARTÍNEZ, José Maria. Convivencia: a strategy that prevents school bullying and promotes emotional health and well-being. In: COWIE, Helen; MYERS, Carrie Anne (Eds.). School Bullying and Mental Health: Risks, Intervention and Prevention. London: Routledge, 2017.

AVILÉS MARTÍNEZ, José María. ELICES SIMÓN, Juan Antonio. Insebull. Instrumentos para la evaluación del bullying. Madrid: CEPE, 2007. 
AVILÉS MARTÍNEZ, José Maria. Manual contra el bullying. Guía para el profesorado. Lima: Libro Amigo, 2012.

AVILÉS MARTÍNEZ, José Maria. Os Sistemas de Apoio entre Iguais na escola. Das equipes de ajuda à cybermentoria. Americana: Adonis, 2018.

AVILÉS MARTÍNEZ, José Maria. Proyecto Antibullying. Prevención del bullying y el cyberbullying en la comunidad educativa. Madrid: CEPE, 2015.

AVILÉS MARTÍNEZ, José Maria. Victimización percibida y bullying. Factores diferenciales entre víctimas. Boletín de Psicología, n. 95, p. 7-28, 2009.

AVILÉS MARTÍNEZ, José María; ALONSO, María Natividad. Caderno de formação das equipes de ajuda. Alunos e alunas: Ensino Fundamental II. Americana, SP: Adonis, 2017a.

AVILÉS MARTÍNEZ, José María; ALONSO, María Natividad. Caderno de formação das equipes de ajuda. Professores e professoras: Ensino Fundamental II. Americana, SP: Adonis, 2017b.

AVILÉS MARTÍNEZ, José Maria; TORRES, Nieves; VIÁN, María Victoria. Equipos de ayuda, maltrato entre iguales y convivencia escolar. Electronic Journal of Research in Educational Psychology, v. 6, n. 3, p. 357-376, 2008.

BOMFIM, Sanderli Aparecida Bicudo. Respeito, justiça e solidariedade no coração de quem ajuda: valores morais e protagonismo entre alunos para combater o bullying. 2019. $210 \mathrm{f}$. Dissertação (Mestrado em Educação Escolar) - Faculdade de Ciências e Letras, Universidade Estadual Paulista, Araraquara, 2019.

BRASIL. Instituto Nacional de Estudos e Pesquisas Educacionais Anísio Teixeira (INEP). Pesquisa Internacional sobre Ensino e Aprendizagem revela impacto do bullying nas escolas. 19 jun. 2019b. Disponível em: http://inep.gov.br/artigo/-

/asset_publisher/B4AQV9zFY7Bv/content/pesquisa-internacional-sobre-ensino-e-aprendizagemrevela-impacto-do-bullying-nas-escolas/21206. Acesso em: 20 jul. 2020.

BRASIL. Instituto Nacional de Estudos e Pesquisas Educacionais Anísio Teixeira (INEP). Programa Internacional de Avaliação de Estudantes (Pisa). 3 dez. 2019a. Disponível em: http://inep.gov.br/pisa. Acesso em 10 jan. 2020.

BRASIL. Lei n. 13.185, de 6 de novembro de 2015. Institui o Programa de Combate à Intimidação Sistemática (Bullying). Diário Oficial da União, Brasília, DF, 9 nov. 2015. Disponível em: http://www.planalto.gov.br/ccivil_03/_ato2015-2018/2015/lei/l13185.htm. Acesso em: 14 set. 2017.

BRASIL. Lei n. 13.663, de 14 de maio de 2018. Diário Oficial da União, Brasília, DF, 15 maio 2018. Disponível em: http://www2.camara.leg.br/legin/fed/lei/2018/lei-13663-14-maio-2018-786678publicacaooriginal-155555-pl.html. Acesso em: 16 maio 2018.

BRASIL. Ministério da Educação (MEC). Especialistas indicam formas de combate a atos de intimidação. 20 abril de 2017. Disponível em: http://portal.mec.gov.br/ultimas-noticias/211- 
218175739/47721-especialistas-indicam-formas-de-combate-a-atos-de-intimidacao. Acesso em: 17 jul. 2020.

COHEN, Jonathan. et al. School climate: research, policy, teacher education and practice. Teachers College Record, v. 111, n. 1, p. 180-213, 2009.

COWIE, Hellen; SMITH, Peter. Violência nas escolas: uma perspectiva do Reino Unido. In: DEBARBIEUX, Éric; BLAYA, Catherine (Orgs.). Violência nas Escolas: dez abordagens européias. Brasíliam, DF: UNESCO, 2002.

COWIE, Hellen; WALLACE, Patti. Peer support in action. London: Sage, 2000.

DEL BARRIO, Cristina et al. Del maltrato y otros conceptos relacionados con la agresión entre escolares, y su estudio psicológico. Infancia y Aprendizaje, v. 26, n. 1, p. 9-24, 2003.

FRICK, Loriane Trombini et al. Estratégias antibullying para o ambiente escolar. Revista IberoAmericana de Estudos em Educação, Araraquara, p. 1152-1181, out. 2019. ISSN 1982-5587. Disponível em: https://periodicos.fclar.unesp.br/iberoamericana/article/view/12380. Acesso em: 16 ago. 2020. DOI: https://doi.org/10.21723/riaee.v14i3.12380

GARTNER, Alan; KOHLER, Mary; RIESSMAN, Frank. Children teach children. Nueva York: Harper Row, 1971.

IDOETA, Paula Adamo. Pisa: alunos brasileiros 'estacionam' em leitura, ciências e matemática e sofrem mais com bullying e solidão. BBC News Brasil, 3 dez. 2019. Disponível em: https://www.bbc.com/portuguese/brasil-50606790. Acesso em: 4 dez. 2019.

JANOSZ, Michel. et al. Witnessing violence in early secondary school predicts subsequent student impairment. J Epidemiol Community Health, 16 set. 2018. Disponível em: https://jech.bmj.com/content/72/12/1117. Acesso em: 4 dez. 2019. DOI: http://dx.doi.org/10.1136/jech-2018-211203

JARES, Xesús. Pedagogia da Convivência. São Paulo: Palas Athena, 2008.

LA TAILLE, Yves de. Vergonha, a ferida moral. Petrópolis, RJ: Vozes, 2002.

LAPA, Luciana Zobel. Valentes contra o bullying: a implantação das Equipes de Ajuda, uma experiência brasileira. 2019. 315 f. Dissertação (Mestrado em Educação Escolar) - Faculdade de Ciências e Letras, Universidade Estadual Paulista, Araraquara, 2019.

LEOPOLDINO, Elcio Rezek; SANTOS, Luiz Anselmo Menezes; CAMINHA, Iraquitan Oliveira. Educação e Fenomenologia: a percepção de adolescentes acerca do bullying na escola. Revista Tempos e Espaços em Educação, v. 13, n. 32, p. 1-22, 22 jul. 2020.

KOVACS, Helena; TINOCA, Luís. Unfreeze the pedagogies: introduction of a new innovative measure in Portugal. Revista Tempos e Espaços em Educação, São Cristóvão - SE, v. 10, n. 23, p. 73-86, 2017.

MENESINI, Ersilia et al. Enhancing children's responsibility to take action against bullying: 
Evaluation of a befriending intervention in Italian middle schools. Aggressive Behavior, n. 29, p. 10-14, 2003.

MENIN, Maria Suzana de Stefano; BATAGLIA, Patrícia Unger Raphael; ZECHI, Juliana Aparecida Matias (Orgs.). Projetos bem-sucedidos de educação em valores: relatos de escolas públicas brasileiras. São Paulo: Cortez Editora, 2013.

NAYLOR, Paul. Anti-bullying peer support systems in school: what are they and do they work? Ponencia impartida. In: INTERNATIONAL CONGRESS OF COMMUNITY LIFE AT SCHOOL, 2., 2010, Almería. Anais [...]. Almería: Universidad de Almeria, 2010.

NAYLOR, Paul.; COWIE, Hellen. The role of peer support systems in education for citizenship. The School Field, v. 11, n. 1-2, p. 131-142, 2000.

OCDE. PISA 2018 Results: excellence and equity in education. Volume I. Paris: OECD Publishing, 2019. Disponível em: https://www.oecd.org/education/pisa-2015-results-volume-i9789264266490-en.htm. Acesso em: 4 dez. 2019.

OLWEUS, Dan. Bully/victim problems in school: Facts and intervention. European Journal of Psychology of Education, v. XII, n. 4, p. 495-510, 1997.

OLWEUS, Dan. Bullying at school. What we know and what we can do. Blackwell: Oxford and Cambridge, 1993.

PEREIRA, Ana Lúcia et al. Educação em valores: possibilidades e responsabilidades na percepção de docentes que atuam na educação pública do estado do Paraná. Revista Tempos e Espaços em Educação, v. 10, n. 22, p. 23-34, 4 maio 2017.

PIAGET, Jean. O Juízo moral na criança. São Paulo: Summus, 1994.

PIKAS, Anatol. The common concern method for the treatment of mobbing. In: ROLAND, Erling; MUNTHE, Elaine (Eds.)., Bullying: an international perspective. London: David Fulton, 1989. p. 91-105.

RIGBY, Ken. Bullying in schools. And what to do about it. Londres: Jessica Kingsley, 1996.

SILVA, Saskia Lavyne Barbosa da; CAMINHA, Iraquitan de Oliveira. Desempenho motor, imagem corporal e bullying escolar. Revista Tempos e Espaços em Educação, v. 7, n. 13, p. 45-54, maio/ago. 2014.

SLAVIN, Robert. Cooperative learning. Theory, research and practice. Massachusetts: Allyn y Bacon, 1995.

SOUSA, Jesus Maria. Repensar o currículo como emancipador. Revista Tempos e Espaços em Educação, São Cristóvão - SE, v. 9, n. 18, p. 111-120, 2016.

TOGNETTA, Luciene Regina Paulino et al. Bullying e cyberbullying: quando os valores morais nos faltam e a convivência se estremece. Revista Ibero-Americana de Estudos em Educação, Araraquara, p. 1880-1900, jul. 2017. ISSN 1982-5587. Disponível em: 
https://periodicos.fclar.unesp.br/iberoamericana/article/view/10036. Acesso em: 16 ago. 2020. DOI: https://doi.org/10.21723/riaee.v12.n.3.2017.10036

TOGNETTA, Luciene Regina Paulino et al. Características das relações entre pares e sua relação com o fenômeno bullying. In: SEMINÁRIO VIOLAR, 1., 2010, Campinas. Anais [...]. Campinas, SP: Unicamp, 2010. Tema: Problematizando as Juventudes na Contemporaneidade.

TOGNETTA, Luciene Regina Paulino et al. The changes in a silent audiencefacing bullying: the brazilian experience about the establishments of helping teams at school. In: ENSEC CONFERENCE, 6., 2017, Stockholm. Anais [...]. Stockholm: ENSEC, 2017.

TOGNETTA, Luciene Regina Paulino. Sentimentos e virtudes: um estudo sobre a generosidade ligada às representações de si. 2005. Tese (Doutorado em Psicologia) - Instituto de Psicologia, Universidade de São Paulo, São Paulo, 2005.

VINHA, Telma Pileggi. et al. Da escola para a vida em sociedade, o valor da convivência democrática. In: TOGNETTA, Luciene Regina Paulino; MENIN, Maria Suzana de Stefano (Orgs.). Coleção Valores Sociomorais: reflexões para a Educação. Americana, SP: Adonis, 2017.

VIVALDI, Flávia Maria de Campos. A função social da escola: a implantação de um projeto institucional para a convivência ética. 2020. 318 f. Tese (Doutorado em Educação) - Faculdade de Educação, Universidade Estadual de Campinas, Campinas, 2010. Disponível em: http://repositorio.unicamp.br/jspui/handle/REPOSIP/342423. Acesso em: 2 jun. 2019.

\section{ABOUT THE AUTHORS}

\section{Luciene Regina Paulino Tognetta}

Professor, Psychology Department, São Paulo State University (UNESP); Faculty of Sciences and Languages (FCLAr/UNESP) - Brazil. Doctorate in School and Human Development Psychology (USP). Leader of the Moral Education Study and Research Group (GEPEM).

E-mail: Irpaulino@uol.com.br

ORCID: http://orcid.org/0000-0003-0929-4925

\section{José Maria Avilés Martínez}

Professor, Psychology Department, University of Valladolid (Uva); Faculty of Education and Social Work Spain.

E-mail: aviles@uva.es

ORCID: http://orcid.org/0000-0001-9179-6427

\section{Darlene Ferraz Knoener}

Doctoral Student in School Education, São Paulo State University (UNESP); Faculty of Sciences and Languages (FCLAr/UNESP) - Brazil. Member of the Moral Education Study and Research Group (GEPEM).

E-mail: darlene.knoener@gmail.com

ORCID: https://orcid.org/0000-0001-7384-7024 


\section{Ana Luiza Aparecida de Matos}

Postgraduate Student in School Education, São Paulo State University (UNESP); Faculty of Sciences and Languages (FCLAr/UNESP) - Brazil. Member of the Moral Education Study and Research Group (GEPEM).

E-mail: ana.luizadematos@hotmail.com

ORCID: http://orcid.org/0000-0001-5587-0079

\section{Sanderli Aparecida Bicudo Bomfim}

Master in School Education, São Paulo State University (UNESP); Faculty of Sciences and Languages (FCLAr/UNESP) - Brazil. Member of the Moral Education Study and Research Group (GEPEM).

E-mail: sanderli.bicudo@gmail.com

ORCID: https://orcid.org/0000-0002-7371-5184

Received On: 09-02-2020.

Approved in: 10-15-2020.

Published in: 11-04-2020. 